\title{
Silvicultural performance of forest species introduced in integrated livestock forest system in Lavras, MG, Brazil
}

\author{
Erick Martins Nieri ${ }^{\text {* }}$ Renato Luiz Grisi Macedo ${ }^{1}$ Nelson Venturin ${ }^{1}$ \\ Regis Pereira Venturin ${ }^{2}$ José Alvim Pinto Júnior ${ }^{1}$ Lucas Amaral de Melo ${ }^{1}$
}

'Departamento de Ciências Florestais, Universidade Federal de Lavras (UFLA), 37200-000, Lavras, MG, Brasil. E-mail: erickenieri@yahoo.com.br. ${ }^{*}$ Corresponding author.

${ }^{2}$ Empresa de Pesquisa Agropecuária de Minas Gerais (EPAMIG), Lavras, MG, Brasil.

\begin{abstract}
The objective of this study was to evaluate the silvicultural performance of four forest species introduced in a setting for integrated livestock forest (ILF) in a pasture in Lavras, Minas Gerais, Brazil. The species included were the Australian red cedar (seminal and clonal), African mahogany, teak, and guanandi. A split plot scheme with a randomized complete block design comprising four replicates and 48 plants per plot, was used in the following arrangement: $(3(3 \times 2)+7 x 2) \mathrm{m}$. The evaluation times $(12,18,31,36$, and $43 \mathrm{months}$ after planting) corresponded to the subplots. Performances of all four species were evaluated on the basis of their survival rate, height (H) and diameter at breast height $(D B H)$. Based on the performance of the species with regard to these parameters, the clonal Australian red cedar showed a greater growth in DBH and height in the ILF setting as compared to the other species, which indicates it to be a suitable species for the region of Lavras, $M G$ as long as its survival control occurs in the implantation phase.
\end{abstract}

Key words: adaptation, species testing, introduction of species.

Desempenho silvicultural de espécies florestais introduzidas em sistema de integração pecuária floresta em Lavras, MG

RESUMO: Objetivou-se com este trabalho avaliar o desempenho silvicultural de quatro espécies florestais introduzidas em arranjo para Integração Pecuária Floresta (IPF) sobre pastagem, em Lavras, Minas Gerais. As espécies estudadas foram o cedro australiano (seminal e clonal), mogno africano, teca e guanandi. Utilizou-se o delineamento de blocos casualizados completos, em esquema de parcelas subdivididas no tempo, com quatro repetições e 48 plantas por parcela no arranjo (3(3x2)+7x2)m. As subparcelas corresponderam às épocas de avaliações $(12,18,31,36$ e 43 meses pós-plantio). Os desempenhos das espécies foram avaliados por meio dos parâmetros de sobrevivência, diâmetro à altura do peito e altura. Com base no desempenho das espécies, o cedro australiano clonal apresentou maior crescimento em DAP e altura no arranjo para IPF sendo esta a espécie indicada para Lavras $/ M G$, desde que na fase de implantação ocorra o controle da sobrevivência. Palavra-chave: adaptação, teste de espécies, introdução de espécies.

\section{INTRODUCTION}

In the southern region of Minas Gerais State (MG), Brazil, there is a predominance of activities that concentrate on dairy farming and agricultural cultivation, especially in small rural properties, which include underutilized areas with some degradation degree. Keeping this in perspective, the optimization and capitalization of these small degraded areas by the introduction of forest species into structural arrangements for Integrated Livestock Forest (ILF) systems is an alternative.
Wood and food production on underutilized pastures through ILF systems is a promising means of reducing the pressure on native forests. They also aid in promoting the sustainability of ecosystems, such as that under consideration in this study, which are subject to degradation, while increasing their productivity per unit area. These improvements are expected to help rural producers in capitalizing natural resources at the end of the forest species cycle (CASTRO et al., 2008).

The ILF is a diversified system that allows the recovery of degraded areas and the production of wood and food within them with low environmental 
side effects. The choice of the forest-based components is fundamental to the success of such a system, since the selected species - whether native or exotic - has to adapt to the edaphoclimatic conditions of the region; the introduced species also has to acknowledge its ecophysiological conditions and acclimatize to the initial ecological groups of succession in order to minimize unforeseen environmental and ecological disturbances (CASTRO et al., 2008; MELOTTO et al., 2009).

There is a limited number of studies that evaluate the performance of forest species in ILFspecific arrangements. Therefore, in the present study, selection of fast-growing forest species with high quality wood has been prioritized for improvement in the final income of the system. The objective of this study was to evaluate the silvicultural performance of four forest species introduced in an ILF arrangement in a pasture in Lavras, MG, Brazil.

\section{MATERIALS AND METHODS}

The experiment was set up in January 2012 at the experimental farm of Agricultural Research Company of Minas Gerais (EPAMIG) located in the city of Lavras, MG. The experimental area presents a dystrophic red latosol; it has a tropical climate with mild summers, which is defined as humid mesothermal type $\mathrm{Cwb}$ weather according to Köppen classification. Temperature of the warmest month is lower than $22^{\circ} \mathrm{C}$ and the average temperature is between $18^{\circ} \mathrm{C}$ and $19^{\circ} \mathrm{C}$. Mean annual precipitation in the experimental area is $1511 \mathrm{~mm}$, ranging from $16.9 \mathrm{~mm}$ in the driest month to $293.9 \mathrm{~mm}$ in the month with the highest precipitation (ALVARES et al., 2013, INMET, 2014).

During the experimental setup, control of leaf-cutting ants, cleaning of the area, and correction as well as preparation of the soil were carried out. These preliminary measures were taken because the area under consideration was a Urochloa decumbens pasture, with symptoms of degradation according to the standards outlined by DIAS FILHO (2011).

Ant control, area cleaning, and maintenance fertilization were carried out during the implantation and development of the study. The area was cleaned in two steps. Firstly, weed control was carried out between lines of planting by the application of herbicide (glyphosate) in the total area with a farm tractor $(4 \times 2$ TDA $)$, the application of weed was performed in batches over time. Soil correction and preparation of the area were done by harrowing (total area) and subsoiling (planting rows). Limestone and simple superphosphate were also applied based on initial chemical analysis of the soil.
According to the initial analysis, which was done at a depth of $0-20 \mathrm{~cm}, \mathrm{pH}$ of soil was 5.90, organic matter content was $1.64 \mathrm{dag}^{-1}$, phosphorus was $7.94 \mathrm{mg}$ $\mathrm{dm}^{-3}$, potassium was $60.00 \mathrm{mg} \mathrm{dm}$, base saturation index was $57.12 \%$, and aluminum saturation index was $0.00 \%$. At the depth of $20-40 \mathrm{~cm}$, pH was 5.70 , organic matter content was $1.52 \mathrm{dag} \mathrm{kg}^{-1}$, phosphorus was $0.56 \mathrm{mg} \mathrm{dm}^{-3}$, potassium was $40.00 \mathrm{mg} \mathrm{dm}^{-3}$, base saturation index was $41.83 \%$, and aluminum saturation index was $0.00 \%$.

To plant the seedlings, $400 \mathrm{ml}$ of hydroretentor polymer was used per plant, and after one month of planting, weed control and fertilization were performed. There was also an addition of $50 \mathrm{~g}$ of NPK (20-0-20) fertilizer. During rainy seasons of the $1^{\text {st }}, 2^{\text {nd }}$, and $3^{\text {rd }}$ year, cover fertilization was performed providing $180 \mathrm{~g}$ of NPK (20-5-20) per plant in each fertilization period.

The seedlings were obtained from nurseries in Lavras, MG and were planted in areas, where pasture was degraded (Urochloa decumbens) after initial soil conditioning. The seedlings were transplanted in an arrangement that comprised three planting rows spaced $3 \times 2 \mathrm{~m}$ apart, separated by a $7 \mathrm{~m}$ planting row with plants spaced $2 \mathrm{~m}$ in the row, which resulted in the final arrangement of $(3(3 \times 2)+7 \times 2) \mathrm{m}$. The final arrangement that was then studied consisted of four planting rows with a total of 56 plants per plot. Forty-eight central plants were considered viable, while the remaining were used to overcome the border effect. Evaluation times of 12, 18, 31, 36, and 43 months post-planting were considered subplots.

The experimental design was a randomized complete block design with four replicates and 48 plants per plot. The treatments were composed of vegetative and seminal propagation of four forest species represented by Toona ciliata M. Roemer (Australian red cedar), Calophyllum brasiliense Cambess (guanandi), Khaya senegalensis A. Juss (African mahogany), and Tectona grandis L. f. (teak).

The response variables used to evaluate the performance of selected species in the proposed arrangement were survival, plant height $(\mathrm{H})$, and diameter at breast height (DBH). In addition to these variables, the Pearson's correlation analysis was performed between $\mathrm{DBH}$, precipitation, and water deficit (12, 18, 31, 36, and 43 months) values obtained from the Agroclimatology Sector of Universidade Federal de Lavras (UFLA) and from the main climatological station of Lavras, MG (EPC).

Observations regarding the survival, $\mathrm{H}$, and DBH variables were subjected to the ShapiroWilk normality test, while the homoscedasticity of 
the variances was subjected to Anscombe and Tukey's test (1963) at 5\% significance level.

Survival results for field seedlings were subjected to normality tests $(p$-value $=0.5126)$ and homoscedasticity of variance ( $\mathrm{F}$ calculated $=0.95$ and F tabulated $=4.74$ ) test, the data was observed to fulfill the assumptions from analysis of variance (ANOVA) (Table 1). The ANOVA was performed using SISVAR software. If the analysis showed significance in the survival data, the Scott-Knott's test at 5\% significance level was applied on it. Regression analysis was performed for each species on their $\mathrm{DBH}$ and $\mathrm{H}$ values (FERREIRA, 2011).

For comparative purposes, the followed survival percentages were considered: Low $(<60 \%)$; moderate $(60-89 \%)$, and high $(>89 \%)$ (Table 1$)$. These values were obtained and validated by the index of replanting of seedlings (MACEDO et al., 2010).

\section{RESULTS AND DISCUSSION}

Teak (100\%) and African mahogany $(87 \%)$ presented higher survival percentage than other species (Table 1 and 2) with the difference being statistically significant. These values were higher for teak as compared to values that have been previously reported, such as in the results of MACEDO et al. (2005), who reported 69\% survival for teak. Results obtained for African mahogany were considered moderate for the survival rate, keeping in view that MELO \& GUIMARÃES (2008) obtained 89\% survival for this species in the Cerrado biome in the $43^{\text {rd }}$ month after planting.
For guanandi, low percentage of survival (43\%) was observed, which may reflect the inherent characteristics of the experimental site. Since this species is originally reported in areas with wet soils, unlike the study area, its requirements were not fulfilled, and thus, it was not able to establish well here and presented reduced growth as well as yellowing and drying of leaves. These characteristics support the hypothesis that guanandi adapts well in regions with higher values of precipitation or in areas near watercourses; this was corroborated by findings reported by MELOTTO et al. (2009), who observed an average survival of $44 \%$ on introduction of native species for ILF in Mato Grosso do Sul, Brazil.

Low survival of clonal and seminal Australian red cedar is attributable to the timing of the experiment, which was implemented at the end of the rainy season, due to which the seedlings did not completely harden-off. This conclusion was drawn considering the little observable change in the morphological characteristics of leaves that is meant to confirm the hardening-off process (DAVIDE et al., 2015). This result is reinforced, when compared with the results obtained by RODRIGUES et al. (2002), who grew Australian red cedar in consortium with coffee. These researchers reported $60 \%$ survival after one year of planting at the end of the rainy period. According to DAVIDE et al. (2015), the hardeningoff process is fundamental to obtaining high survival of the species in the field, since the gradual process of exposure of the seedlings to the sun and reduction of the irrigation period helps them adapt more to the conditions of water stress present in the field.

Table 1 - Summary of variance analysis for height $(\mathrm{m})$ and DBH $(\mathrm{cm})$ for clonal and seminal Australian red cedar, teak, African mahogany, and guanandi at the ages of $12,18,31,36$, and 43 months.

\begin{tabular}{|c|c|c|c|c|}
\hline \multirow{2}{*}{$\mathrm{SV}^{1}$} & \multirow{2}{*}{$\mathrm{DF}^{2}$} & Survival (\%) & Height (m) & $\mathrm{DBH}(\mathrm{cm})$ \\
\hline & & $\mathrm{MS}^{3}$ & MS & MS \\
\hline Species & 4 & $12952.110736^{*}$ & $15.687156^{*}$ & $35.006073^{*}$ \\
\hline Block & 3 & $481.067972^{\mathrm{ns}}$ & $0.058836^{\mathrm{ns}}$ & $0.594972^{\mathrm{ns}}$ \\
\hline Error 1 & 12 & 405.577882 & 0.317226 & 0.490127 \\
\hline Time & 4 & $223.205351^{*}$ & $8.018156^{*}$ & $13.360528^{*}$ \\
\hline Error 2 & 12 & 10.973870 & 0.022156 & 0.056089 \\
\hline Time ${ }^{*}$ Species & 16 & $29.310037^{*}$ & $0.354441^{*}$ & $0.918212^{*}$ \\
\hline Error 3 & 46 & 10.123232 & 0.042311 & 0.107340 \\
\hline $\mathrm{CV} 1^{4}(\%)$ & - & 29.54 & 28.57 & 28.98 \\
\hline $\mathrm{CV} 2^{5}(\%)$ & - & 4.86 & 7.55 & 9.8 \\
\hline $\mathrm{CV} 3^{6}(\%)$ & - & 4.67 & 10.43 & 13.56 \\
\hline Overall average & - & 68.17 & 1.97 & 2.42 \\
\hline
\end{tabular}

${ }^{1}$ Source of variation; ${ }^{2}$ Degree of freedom; ${ }^{3}$ Mean square; ${ }^{4}$ Coefficient of variation referring to error $1 ;{ }^{5}$ Coefficient of variation referring to error $2 ;{ }^{6}$ Coefficient of variation referring to error $3 ;{ }^{\text {ns }}$ Not significant at $5 \%$ significance level; * Significant at $5 \%$ significance level. 


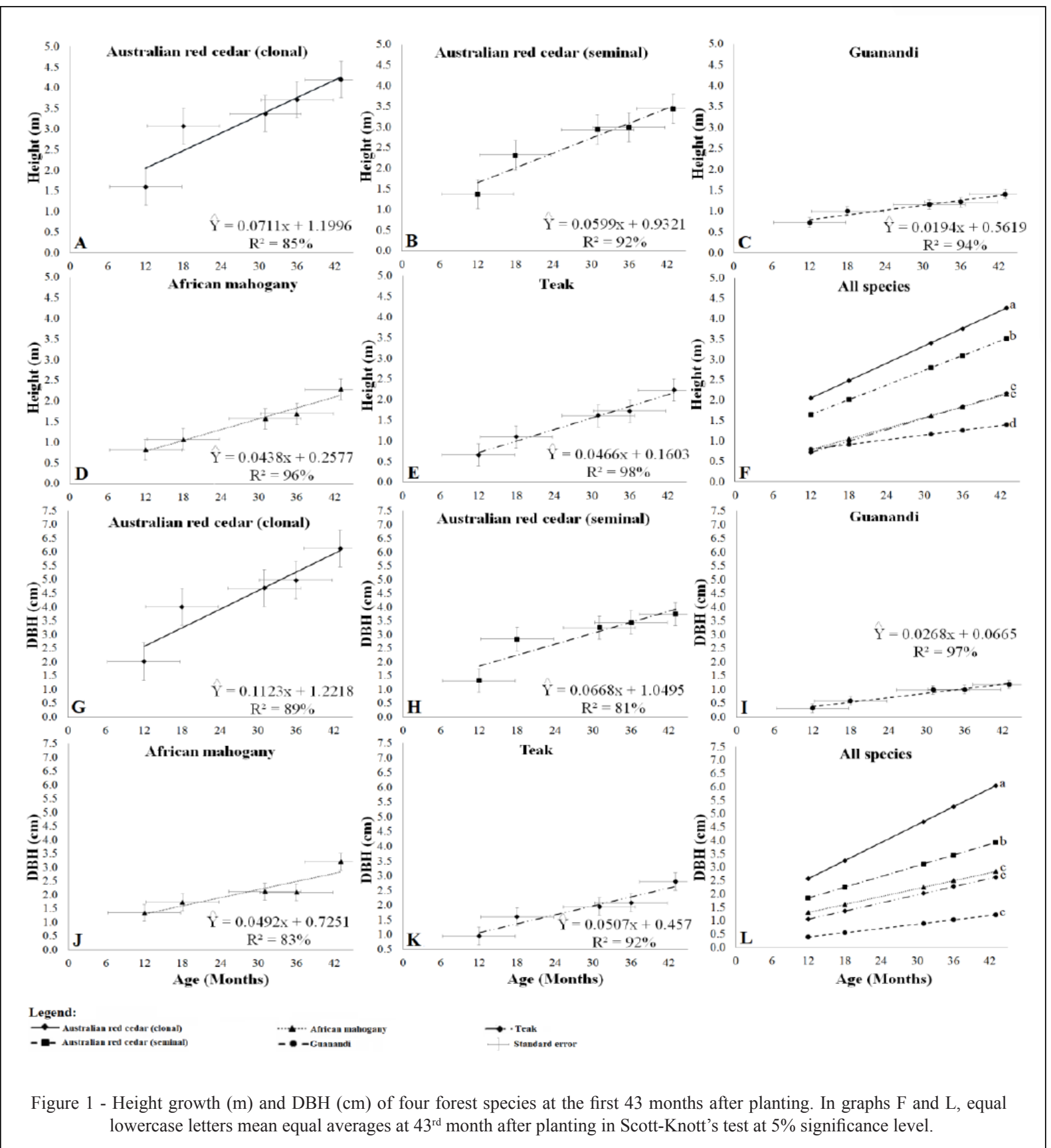

Survival of a species is the initial parameter that can demonstrate its potential to adapt in a given region. However, according to TERRA et al. (2016), it is necessary to analyze the values of parameters that are important from silvicultural aspect (such as $\mathrm{H}$ and $\mathrm{DBH}$ ) in order to measure the development of the species meant to be used in the arrangement, and thus, highlighting species with the greatest potential for plantation in the rural properties of the region under consideration.

It is observable in figure 1 and table 2 that the species studied here presented a linear behavior, demonstrating that they remained in a state of full growth until the last evaluation. Clonal Australian red cedar presented the highest height growth rate $(4.45 \mathrm{~m}$ year $^{-1}$ ), confirming its potential to adapt to the local edaphoclimatic conditions of MG.

The silvicultural performance of the clonal Australian red cedar may be considered satisfactory, when compared to the study conducted by SAKCHOOWONG et al. (2008), who reported a height of $1.66 \mathrm{~m}$ in the $12^{\text {th }}$ month of plantation for Australian red cedar. FASSOLA et al. (2010) reported 
Table 2 - Average survival, height and DBH of four forest species in the arrangement $(3(3 \times 2)+7 \times 2) \mathrm{m}$ for Lavras, MG, in 12, $18,31,36$ and 43 months after planting.

\begin{tabular}{|c|c|c|c|c|c|c|c|c|c|c|}
\hline \multirow{3}{*}{ Species } & \multicolumn{10}{|c|}{ - } \\
\hline & \multicolumn{2}{|l|}{12} & \multirow[t]{2}{*}{18} & \multicolumn{3}{|c|}{31} & \multicolumn{2}{|l|}{36} & \multicolumn{2}{|c|}{43} \\
\hline & \multicolumn{9}{|c|}{ Survival (\%) } & \\
\hline Australian red cedar (Clonal) & 49 & $\mathrm{~b}$ & 49 & $\mathrm{~b}$ & 49 & $\mathrm{~b}$ & 49 & $\mathrm{~b}$ & 45 & $\mathrm{~b}$ \\
\hline Australian red cedar (Seminal) & 54 & $\mathrm{~b}$ & 54 & $\mathrm{~b}$ & 51 & $\mathrm{~b}$ & 49 & $\mathrm{~b}$ & 43 & $\mathrm{~b}$ \\
\hline Guanandi & 58 & $\mathrm{~b}$ & 56 & $\mathrm{~b}$ & 49 & $\mathrm{~b}$ & 49 & $\mathrm{~b}$ & 42 & $\mathrm{~b}$ \\
\hline African mahogany & 97 & a & 95 & a & 90 & a & 90 & a & 87 & $\mathrm{a}$ \\
\hline Teak & 100 & $\mathrm{a}$ & 100 & a & 100 & $\mathrm{a}$ & 100 & $\mathrm{a}$ & 100 & a \\
\hline \multicolumn{11}{|c|}{ 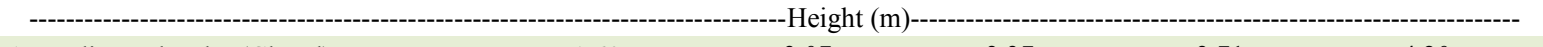 } \\
\hline Australian red cedar (Clonal) & 1.60 & $\mathrm{a}$ & 3.07 & a & 3.37 & $\mathrm{a}$ & 3.71 & a & 4.20 & a \\
\hline Australian red cedar (Seminal) & 1.37 & a & 2.32 & $\mathrm{~b}$ & 2.93 & a & 2.99 & $\mathrm{~b}$ & 3.45 & $\mathrm{~b}$ \\
\hline Guanandi & 0.73 & $\mathrm{~b}$ & 1.00 & $\mathrm{c}$ & 1.16 & $\mathrm{~b}$ & 1.22 & d & 1.41 & d \\
\hline African mahogany & 0.82 & $\mathrm{~b}$ & 1.07 & $\mathrm{c}$ & 1.57 & $\mathrm{~b}$ & 1.69 & $\mathrm{c}$ & 2.28 & $\mathrm{c}$ \\
\hline Teak & 0.66 & $\mathrm{~b}$ & 1.10 & $\mathrm{c}$ & 1.61 & $\mathrm{~b}$ & 1.72 & $\mathrm{c}$ & 2.23 & $\mathrm{c}$ \\
\hline \multicolumn{11}{|c|}{ 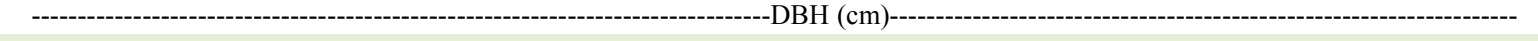 } \\
\hline Australian red cedar (Clonal) & 2.02 & a & 4.01 & a & 4.69 & a & 4.98 & a & 6.13 & a \\
\hline Australian red cedar (Seminal) & 1.33 & $\mathrm{~b}$ & 2.84 & $\mathrm{~b}$ & 3.25 & $\mathrm{~b}$ & 3.44 & $\mathrm{~b}$ & 3.74 & $\mathrm{~b}$ \\
\hline Guanandi & 0.33 & $\mathrm{c}$ & 0.59 & d & 0.99 & d & 1.00 & d & 1.19 & d \\
\hline African mahogany & 1.35 & $\mathrm{~b}$ & 1.74 & $\mathrm{c}$ & 2.12 & $\mathrm{c}$ & 2.12 & c & 3.20 & $\mathrm{c}$ \\
\hline Teak & 0.95 & $\mathrm{c}$ & 1.61 & $\mathrm{c}$ & 1.95 & $\mathrm{c}$ & 2.08 & $\mathrm{c}$ & 2.80 & $\mathrm{c}$ \\
\hline
\end{tabular}

*Averages that are followed by the same lowercase letters in the column do not differ significantly as per the Scott-Knott's test at $5 \%$ significance level.

an average height of $4.00 \mathrm{~m}$ in the $24^{\text {th }}$ month after plantation, which demonstrates the potential of the species to adapt in the region, since in the $18^{\text {th }}$ month, the species had a height of $3.07 \mathrm{~m}$.

The results recorded for African mahogany $(0.82 \mathrm{~m})$ and guanandi $(0.73 \mathrm{~m})$ in the $12^{\text {th }}$ month were satisfactory, when their values were compared to those obtained by FALES and BUENO (1999) and SOUZA et al. (2001), who reported an average height of $0.75 \mathrm{~m}$ in a silvipastoral system for African mahogany and $0.30 \mathrm{~m}$ for guanandi, respectively, in the recovery areas of the Rio Grande basin in MG.

MACEDO et al. (2004) studied teak growth in Lavras, MG and reported an average height of $0.71 \mathrm{~m}$ in the $12^{\text {th }}$ month after planting. Similar values $(0.66 \mathrm{~m})$ were recorded in the present study, which is attributable to the comparable edaphoclimatic conditions. However, MORETTI et al. (2014) obtained seedlings with a height of $1.09 \mathrm{~m}$ in the $12^{\text {th }}$ month in Figueirópolis D'Oeste, MS, which may due to the lower altitude, i.e., $266 \mathrm{~m}$ above sea level, in case of their site of study as well as the higher annual average temperatures that were between $25^{\circ} \mathrm{C}$ and $38^{\circ} \mathrm{C}$, in comparison to the climatic conditions of Lavras, MG that has monthly average temperatures varying between 15 and $28^{\circ} \mathrm{C}$ and the average altitude of $890 \mathrm{~m}$ above sea level. These factors, according to DANTAS et al. (2007), limit the growth of the species.

The height observed for teak plants $(1.61 \mathrm{~m})$ in the $31^{\text {st }}$ month was considered low as compared to the results reported by MACEDO et al. (2005), who obtained plants with $2.8 \mathrm{~m}$ height in the $24^{\text {th }}$ month in Paracatu, MG. This poor performance of teak is probably due to the large number of sprouts that grew during the evaluation period along with the lowest average monthly temperatures and the highest local altitude. The secondary sprouting process of teak usually results in a reduction in the average height of the plant, as sprouting requires more energy for the secondary meristem to grow than the primary meristem (MACEDO et al., 2004).

For DBH (Figure 1 and table 2), it was reported that all species studied here exhibited full growth because they had a linear behavior for this parameter during the period in which the evaluations were done. However, after the $12^{\text {th }}$ month, it was observed that the clonal Australian red cedar had a higher increase in DBH as compared to the other plants analyzed in this investigation.

In the $12^{\text {th }}$ month, the results for clonal $(2.02 \mathrm{~cm})$ and seminal $(1.33 \mathrm{~cm})$ Australian red cedar 
resembled the ones reported by SAKCHOOWONG et al. (2008), who reported a $2.30 \mathrm{~cm} \mathrm{DBH}$ for individual plants of Australian red cedar that had been genetically improved to be resistant against Hypsipyla robusta attack and DBH of $1.30 \mathrm{~cm}$ for individuals susceptible to Hypsipyla robusta (without genetic improvement). These values, in addition to the genetic material, explain the difference in performance of clonal and seminal seedlings of Australian red cedar; the higher secondary growth rate is a result of the degree of improvement for this species.

African mahogany and teak seedlings with DBH of $0.82 \mathrm{~cm}$ and $0.66 \mathrm{~cm}$, respectively, in the $12^{\text {th }}$ month showed poor performance as compared to the seedlings in the research performed by GUIMARÃES NETO et al. (2004) in Brasília, DF and TONINI et al. (2009) in Paraná. These research groups observed $2.60 \mathrm{~cm}$ and $1.43 \mathrm{~cm} \mathrm{DBH}$ for African mahogany and teak, respectively, in the $12^{\text {th }}$ month.

Growth of clonal Australian red cedar with regard to $\mathrm{DBH}$ was $5.00 \mathrm{~cm}$ in the $36^{\text {th }}$ month after planting in comparison to the data presented in RICKEN et al. (2011), with observed a DBH of $5.00 \mathrm{~cm}$ in the $36^{\text {th }}$ month after planting Australian red cedar in the municipality of Adrianopolis, PR. The values of $\mathrm{DBH}$ rported for teak $(1.72 \mathrm{~cm})$ and African mahogany $(1.69 \mathrm{~cm})$ are; however, lower than those reported by MACEDO et al. (2005), who observed a DBH of $4.10 \mathrm{~cm}$ for teak in the $36^{\text {th }}$ month. These values are also lower that those obtained by GUIMARÃES NETO et al. (2004), who recorded a DBH of $3.89 \mathrm{~cm}$ for African mahogany. Low performance in $\mathrm{DBH}$ for African mahogany, teak, and guanandi may possibly be due to the climatic conditions that are characterized by a reduction in annual average precipitation and an increase in water deficit between $31^{\text {st }}$ and $36^{\text {th }}$ month (Figure 2).

When correlating the average precipitation in the periods that were evaluated in the investigation with the increase in $\mathrm{DBH}$, a positive correlation was reported for clonal (0.98) and seminal (0.93) Australian red cedar, teak (0.87), African mahogany (0.60), and guanandi (0.60). It is concluded from this correlational analysis that there is an increase in $\mathrm{DBH}$, when precipitation decreases. Conversely, when correlating water deficit and $\mathrm{DBH}$, a negative correlation was observed for clonal (-0.81) and seminal (-0.63) Australian red cedar, teak $(-0.79)$, guanandi $(-0.45)$, and African mahogany (-0.57), i.e., higher water deficit reduces the secondary growth of all four species.

It was also observed that the lowest average annual precipitation occurred in the $3^{\text {rd }}$ year with $1148.90 \mathrm{~mm}$ year ${ }^{-1}$, which is considered below average for the region of Lavras, MG, with the normal average being $1510 \mathrm{~mm}$ year $^{-1}$ (INMET, 2014). On analysis of past climate in the region of Lavras for the period between

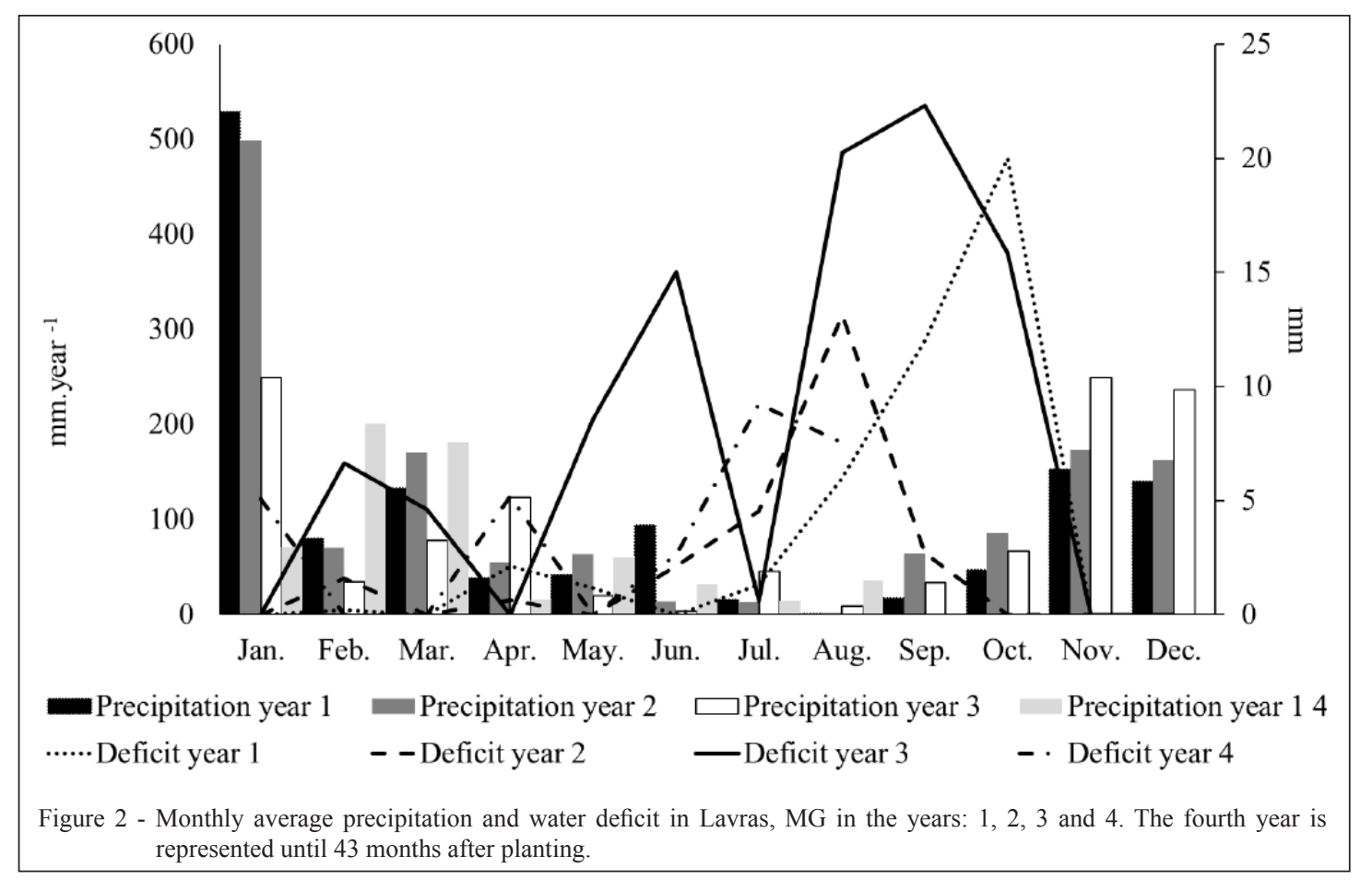

Ciência Rural, v.47, n.12, 2017. 
1960 and 2004, DANTAS et al. (2007) reported average rainfall to be $1495 \mathrm{~mm}^{\text {year }}{ }^{-1}$. According to STAPE et al. (2010), during the dry season, growth and $\mathrm{CO}_{2}$ fixation in the aerial parts of plants decrease, whereas they increase in the root system, causing a reduction in $\mathrm{H}$ and $\mathrm{DBH}$. In general, a reduction in precipitation and an increase in water deficit was observed to influence the growth of plants. However, during the $36^{\text {th }}$ and $43^{\text {rd }}$ months, growth in diameter and height resumed; this incident coincided with an increase in precipitation, and consequently, a reduction in water deficit.

It has been deduced from the observations made in this research that specific factors determine the different performance of species in ILF arrangements. The main limiting factor for Australian red cedar growth probably was the reduction in annual mean precipitation. According to PUMIJUMNONG \& BUAJAN (2013), the species does not develop in dry periods because water deficit reduces the rate of cambial activity, which is reestablished with the increase in average annual precipitation.

According to soil analysis performed at the experimental site, $\mathrm{Ca}$ content and the base saturation for teak in the area were below the recommendations by BARRA (1996), who stressed that the $\mathrm{Ca}$ content should be between 21 and $30 \mathrm{cmol} \mathrm{dm}^{-1}$ for teak to develop adequately.

For guanandi, the limiting component for development was possibly water restriction, which was caused by the reduction in the annual average precipitation. This species is normally reported in humid sites with sufficient water and high precipitation (SOUZA et al., 2001). However, for African mahogany, reduction in precipitation period was probably the limiting factor responsible for its low performance. This is true considering PINHEIRO et al. (2011) and CORCIOLI et al. (2016) observation that this species needs deep soils with high fertility and average annual precipitation of 1300 to $1800 \mathrm{~mm}$ for healthy growth.

It is worth mentioning here that studies on silvicultural performance, based on dendrometric variables, such as $\mathrm{H}$ and $\mathrm{DBH}$, make it possible to express the potential of establishment, growth, and differentiated development of different species, which are essential for the development of agroforestry. These studies are also important to evaluate and analyze the behavior of the herbaceous components inserted in ILF systems so that a better understanding of the interaction between the components involved in such forest systems can be ensured.

\section{CONCLUSION}

The species studied here had different potentials for survival, which were as follows: Teak, high potential: African mahogany, moderate potential; Australian red cedar (clonal and seminal) and guanandi, low potential.

The clonal Australian red cedar exhibited superior silvicultural performance with regard to its DBH and $\mathrm{H}$ for its use in ILF arrangement, which indicates the species to be suitable for growth in Lavras, MG as long as its survival control occurs in the implantation phase.

Among the species studied, guanandi had the lowest silvicultural performance (survival, DBH, and $\mathrm{H}$ ) with maximal symptoms of maladaptation to the experimental site.

\section{ACKNOWLEDGEMENTS}

We thank Coordenação de Aperfeiçoamento de Pessoal de Nível Superior (CAPES) for providing a scholarship to Erick Martins Nieri for this research was provided by Conselho Nacional de Desenvolvimento Científico e Tecnológico (CNPq) and Fundação de Amparo à Pesquisa do Estado de Minas Gerais (FAPEMIG).

\section{REFERENCES}

ALVARES, C.A. et al. Köppen's climate classification map for Brazil. Meteorologische Zeitschrift, v.22, n.6, p.711-728, 2013. Available from: <http://dx.doi.org/doi10.1127/0941-2948/2013/0507>. Accessed: Dez. 05, 2015. doi: 10.1127/0941-2948/2013/0507.

BARRA, O.S.V. Productividad y relaciones del índice de sitio con variables fisiográficas, edafoclimáticas y foliares para Tectona grandis, Bombacopsis quinatum (Jacq.) Dugand y Gmelina arbórea Roxb. Costa Rica. 1996. 168f. Dissertação (Mestrado em Desenvolvimento e conservação) - Centro Agronômico Tropical de Investigacion y Ensenanza, Turrialba.

CASTRO, A.C. et al. Sistema silvipastoril na Amazônia: ferramenta para elevar o desempenho produtivo de búfalos. Ciência Rural, v.38, n.8, p. 2395-2402, 2008. Available from: <http://dx.doi. org/10.1590/S0103-84782008000800050>. Accessed: Nov. 15, 2015. doi: 10.1590/S0103-84782008000800050.

CORCIOLI, G. et al. Deficiência de macro e micronutrientes em mudas maduras de Khaya ivorensis estudadas em viveiro. Cerne, v.22, n.1, p. 131-128, 2016. Available from: < http://dx.doi.org/10 $.1590 / 01047760201622012085$ > . Accessed: Mar. 05, 2017. doi: $10.1590 / 01047760201622012085$

DANTAS, A.A.A. et al. Comunicação classificação e tendências climáticas em Lavras, MG. Ciência e Agrotecnologia, v.31, n.6, p.1862-1866, 2007. Available from: $<$ http://dx.doi.org/ 10.1590/S141370542007000600039>. Accessed: Nov. 10, 2015. doi: 10.1590/S141370542007000600039 .

DAVIDE, A.C. et al. Fatores que afetam a qualidade de mudas destinadas aos projetos de restauração de ecossistemas florestais. 
In: DAVIDE, A.C.; BOTELHO, S.A. Fundamentos e métodos de restauração de ecossistemas florestais: 25 anos de experiência em matas ciliares. Lavras: UFLA, 2015. Cap. 5, p.181-274.

DIAS FILHO, M.B. Os desafios da produção animal em pastagens na fronteira agrícola brasileira. Revista Brasileira de Zootecnia, v.40, p.243-252, 2011.

FALES, I.C.; BAENA, A.R.E. Mogno-africano Khaya ivorensis A. Chev. em sistema silvipastoril com leguminosa e revestimento natural do solo. Belém: Embrapa Amazônia Oriental, 1999. 52p. (Embrapa Amazônia Oriental. Documentos, 4).

FASSOLA, H.E. et al. Pautas para el manejo silvícola de bosques mixtos de Grevillea robusta y Toona ciliata en el sur de la provincia de Misiones. In: JORNADAS TÉCNIAS FORESTALES Y AMBIENTALES FACULTAD DE CIENCIAS FORESTALES, 14., 2010, Eldorado. Anais... Eldorado: UNaM -EEA Montecarlo, INTA, 2010. p.11.

FERREIRA, D.F. Sisvar: a computer statistical analysis system. Ciência e Agrotecnologia, v.35, n.6, p.1039-1042, 2011. Available from: <http://dx.doi.org/10.1590 /S1413705420110 00600001>. Accessed: Nov. 10, 2015. doi: 10.1590 /S1413705420110 00600001.

GUIMARÃES NETO, A.B. et al. Avaliação do plantio homogêneo de mogno, Swietenia macrophylla king, em comparação com o plantio consorciado com Eucalyptus urophylla s. t. blake, após 40 meses de idade. Revista Árvore, v.28, n.6, p.777-784, 2004. Available from: $<$ http://dx.doi.org/10.1590/S0100-67622004000600002>. Accessed: Nov. 25, 2015. doi: 10.1590/S0100-67622004000600002.

INMET. Normais climatológicas. Available from: $<$ http://www.inmet. gov.br/portal/index. php?r=clima/normais $>$. Accessed: Mar. 03, 2015.

MACEDO, R.L.G. et al. Desenvolvimento inicial de Tectona grandis (teca) em diferentes espaçamentos no município de Paracatu, MG. Cerne, v.11, n.1, p.61-69, 2005.

MACEDO, R.L.G. et al. Estabelecimento de Tectona grandis (Teca) em sistemas agroflorestais com Coffea arábica L. em Lavras-MG. Agrossilvicultura, v.1, n.1, p.71-80, 2004.

MACEDO, R.L.G. et al. Eucalipto em sistemas agroflorestais. Lavras: UFLA, 2010. 331p.

MELO, J.T.; GUIMARÃES, D.P. Sistemas agroflorestais no cerrado com guariroba (Syagrus oleraceae Becc.). In: SIMPÓSIO NACIONAL DO CERRADO, 9.; SIMPÓSIO INTERNACIONAL DAS SAVANAS TROPICAIS, 2., 2008, Brasília. Anais... Brasília: Embrapa Cerrado, 2008. p.1-6.

MELOTTO, A. et al. Sobrevivência e crescimento inicial em campo de espécies florestais nativas do Brasil central indicadas para sistemas silvipastoris. Revista Árvore, v.33, n.3, p.425432, 2009. Available from: <http://dx.doi.org/10.1590/S010067622009000300004>. Accessed: Nov.15, 2015. doi: 10.1590/ S0100-67622009000300004.

MORETTI, M.S. et al. Crescimento inicial de plantas de teca em monocultivo e sistema Taungya com milho em Figueiropolis D'Oeste, Estado de Mato Grosso. Scientia Forestalis, v.42, n. 102, p. 269-277. 2014.

PINHEIRO et al. Ecologia, silvicultura e tecnologia de utilização dos mognos africanos (Khaya spp.). Viçosa: Sociedade Brasileira de Agrossilvicultura, 2011. 102p.

PUMIJUMNONG, N.; BUAJAN, S. Seasonal cambial activity of five tropical tree species in central Thailand. Trees, v.27, p.409-417, 2013. Available from: <http://dx.doi.org/10.1007/ s0046801207944>. Accessed: Dez. 15, 2015. doi: 0.1007/s0046801207944.

RICKEN, P. et al. Crescimento diâmetro de povoamento de Toona ciliata var. australis em Adrianópolis, PR. Colombo: Embrapa Floresta, 2011. 4p. (Comunicado técnico n.28).

RODRIGUES, V.G.S. et al. Estabelecimento e crescimento inicial de espécies florestais consorciadas em lavouras de café robusta (Coffea canephora) em Rondônia. Porto Velho: Embrapa, 2002. 4p. (Comunicado Técnico 58).

SAKCHOOWONG, W. et al. Effects of tree shade on attacks by the red cedar shoot borer, Hypsipyla robusta (Moore) (Lepidoptera: Pyralidae). Kasetsart Journal: Natural Science, v.42, n.1, p.435-443, 2008.

SOUZA, P.A. et al. Estabelecimento de espécies arbóreas em recuperação de área degradada pela extração de areia. Cerne, v.7, n.2, p.043-052, 2001.

STAPE, J.L. et al. The Brazil eucalyptus potential productivity project: influence of water, nutrients and stand uniformity on wood production. Forest Ecology and Management, v.259, p.1684-1694, 2010. Available from: <https://doi.org/10.1016/ jforeco201001012>. Accessed: Dez. 15, 2016. doi: 10.1016/ jforeco201001012.

TERRA, M.I.C. et al. Growth dynamics of rubber tree clones in northwestern Minas Gerais, Brazil. Ciência Rural, v.46, n.6, p.10321037, 2016. <http://dx.doi.org/10.1590/0103-8478cr20150268>. Accessed: Dez. 15, 2016. doi: 10.1590/0103-8478cr20150268.

TONINI, H. et al. Crescimento da teca (Tectona grandis) em reflorestamento na Amazônia Setentrional. Pesquisa Florestal Brasileira, v.59, n.1, p.05-14, 2009. Available from: <https :// doi.org/10.4336/2009.pfb.59.05>. Accessed: Dez. 15, 2016. doi: 10.4336/2009.pfb.59.05. 